\title{
Crisis, work and nursing: an ethnographic narrative of the coronavirus pandemic in Primary Care in Spain
}

\author{
Crise, trabalho e enfermagem: narrativa etnográfica da pandemia por coronavírus na Atenção Primária da Espanha
}

Crisis, trabajo y enfermería: una narrativa etnográfica de la pandemia de coronavirus en Atención Primaria en España

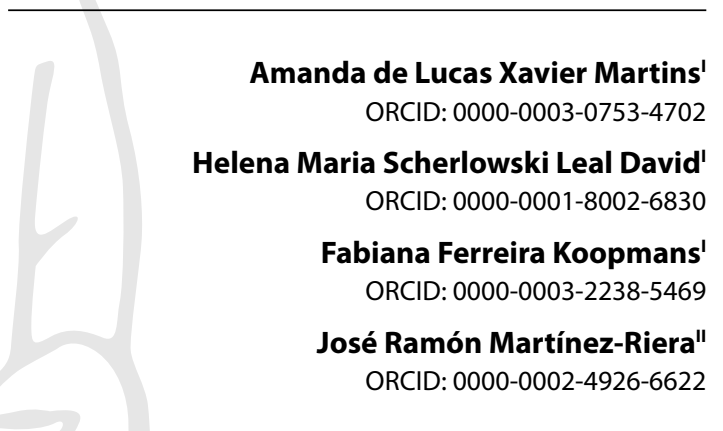

'Universidade do Estado do Rio de Janeiro. Rio de Janeiro, Rio de Janeiro, Brazil.

"Universidad de Alicante. Alicante, España.

How to cite this article: Martins ALX, David HMSL, Koopmans FF, Martínez-Riera JR. Crisis, work and nursing: an ethnographic narrative of the coronavirus pandemic in Primary Care in Spain. Rev Bras Enferm. 2022;75(Suppl 1):e20210069. https://doi.org/10.1590/0034-7167-2021-0069

Corresponding author:

Amanda de Lucas Xavier Martins

E-mail:amandaxenf@gmail.com

EDITOR IN CHIEF: Dulce Barbosa ASSOCIATE EDITOR: Maria Itayra Padilha

Submission: 02-24-2021 Approval: 06-24-2021

\section{RESUMO}

Objetivo: narrar a experiência do enfrentamento de uma longa crise econômico-política e a vivência do processo da chegada da pandemia do coronavírus em um centro de saúde espanhol. Métodos: trata-se de estudo descritivo qualitativo com análise etnográfica, com coleta de dados por entrevistas, observação participante e registros em diário de campo. Resultados: a imersão no contexto permitiu identificar dois eixos de domínio: "a crise, o trabalho na comunidade e o território na Atenção Primária"; "da inevitabilidade do ser enfermeiro no enfrentamento da crise sanitária". Considerações finais: a narrativa retrata a ético na pesquisa de campo, tensões e valores do trabalho da enfermagem em conjuntura de crise. A experiência dos enfermeiros é trazida em narrativas de insatisfação e dificuldades, porém com a sustentação de valores relacionados à garantia da assistência aos usuários e de cooperação e solidariedade na organização coletiva dos trabalhadores para enfrentamento da crise da COVID-19.

Descritores: Antropologia Cultural; Atenção Primária à Saúde; Enfermagem; Infecções por Coronavirus; Enfermagem em Saúde Comunitária.

\section{ABSTRACT}

Objective: to narrate the experience of facing a long economic and political crisis and the experience of the arrival process of the coronavirus pandemic in a Spanish healthcare center. Methods: this is a descriptive qualitative study with ethnographic analysis, with data collection through interviews, participant observation and field diary records. Results: the immersion in the context allowed us to identify two axes of domain: "The crisis, work in the community and the territory in Primary Care"; "The inevitability of being a nurse in facing a health crisis". Final considerations: the narrative portrays the ethics in field research, tensions and values of nursing work in crisis situations. Nurses' experiences are presented in narratives of dissatisfaction and difficulties, but with the support of values related to guaranteeing assistance to users and cooperation and solidarity in the collective organization of workers to face the COVID-19 crisis. Descriptors: Anthropology, Cultural; Primary Health Care; Nursing; Coronavirus Infections; Community Health Nursing.

\section{RESUMEN}

Objetivo: narrar la experiencia de afrontar una larga crisis económico-política y la experiencia del proceso de llegada de la pandemia de coronavirus en un centro sanitario español. Métodos: se trata de un estudio cualitativo descriptivo con análisis etnográfico, con recolección de datos a través de entrevistas, observación participante y registros de diario de campo. Resultados: la inmersión en el contexto permitió identificar dos ejes de dominio:"La crisis, el trabajo en la comunidad y el territorio en Atención Primaria"; "De la inevitabilidad de ser enfermero ante la crisis sanitaria". Consideraciones finales: la narrativa retrata la ética en la investigación de campo, las tensiones y los valores del trabajo de enfermería en situaciones de crisis. La experiencia de las enfermeras se presenta en narrativas de insatisfacción y dificultades, pero con el respaldo de valores relacionados con garantizar la asistencia a los usuarios y la cooperación y solidaridad en la organización colectiva de los trabajadores para enfrentar la crisis del COVID-19. Descriptores: Antropología Cultural; Atención Primaria de Salud; Enfermería; Infecciones por Coronavirus; Enfermería en Salud Comunitaria. 


\section{INTRODUCTION}

The serious public health situation caused by the new coronavirus (COVID-19) has an initial milestone in the verification of the increase in the number of severe pneumonias in China at the end of 2019. Considering the rapid and high potential for spread and the pressure on the responsiveness of health systems to respond to severe cases, the World Health Organization has declared a Public Health Emergency of International Importance. Shortly thereafter, the body, on March 11, 2020, classified the coronavirus 2019 disease as a pandemic ${ }^{(1)}$.

Although the problems related to COVID-19 in the Brazilian national territory have imposed an extremely difficult setting, it is considered important to rescue the experience of the beginning of this health crisis with healthcare professionals from another country to collaborate in the reflection on coping with Epidemic. We return to the beginning of 2020, when one of the authors was in field research in Europe, the epicenter of the disease at the time, with Italy and Spain being its two main focuses. After rereading and analyzing the collected data, the importance of bringing this narrative of coping with COVID-19 in the country where the research was developed was realized, Spain, in which an attempt was also made to understand the experience of a serious political-economic crisis that affected the European continent from 2008 onwards.

The fundamental elements to understand the initial outcome of the epidemic in European countries are related to the population's special vulnerability, mostly composed of elderly people, with the presence of chronic comorbidities, corresponding in Spain to $87.6 \%$ of deaths by COVID-19(2). Allied to this profile, during the period of stay, there was the health system's inability to respond, which, as in most countries, did not have the necessary contribution for the volume of care given the rapid explosion in the number of cases. The main health measures in Spain were developed in the hospital environment, such as closure of Primary Care centers and the displacement of professionals to campaign hospitals $\mathrm{s}^{(3)}$. Epidemics must be considered as a social fact, within the broad context of social production and reproduction ${ }^{(4)}$. It is not by chance that economic-political crises unfold into health crises, with the epidemic being one of the sharpest faces of contradictions in this mode of production. It can be said that the COVID-19 pandemic has a deep relationship with the structural crisis of the capitalist mode of production ${ }^{(5)}$ and has direct impacts of restrictions for users and healthcare professionals.

The demand for care is cumulatively added to the impacts of budget cuts on health systems, which entail high emotional distress and suffering for professionals. Nevertheless, the experience of workers' struggle for the defense of life in the trenches of health systems, show the subjectivation of values and collective organization to face the crisis. Amidst the chaos installed by the pandemic in the world, and more specifically in the Spanish setting, field research was carried out to address the impacts of long economic-political crisis of capitalism on nursing professionals' daily lives in Spanish Primary Care. It is from this perspective that we are going to narrate nurses' experiences of coping with the crisis, and the experience of research at the beginning of the most acute process of the COVID-19 epidemic in the country in question. It is an ethnographic narrative from the imponderable crossing of the COVID-19 epidemic in the research setting.

\section{OBJECTIVE}

To narrate the experience of facing a long economic and political crisis and the experience of the arrival process of the coronavirus pandemic in a Spanish healthcare center.

\section{METHODS}

\section{Ethical aspects}

The data presented are the product of data collection for carrying out the sandwich doctoral thesis in progress at the Universidade do Estado do Rio de Janeiro, Rio de Janeiro, Brazil and at the Universidad de Alicante, Autonomous Community of Valencia, Spain, with the objective is to understand the impacts of the political economic crisis, between 2008 and 2019, on nurses' work in primary care in Spain and Brazil. Data collection was being carried out in Spain at the time the COVID-19 pandemic broke out. Thus, this article brings the narrative of the experience of one of the authors during data collection, based on participant observation, interviews in Spanish health units and field diary records, with the object of discussion being the experience facing the situations of crisis by professionals and the problems experienced in Primary Care by the COVID-19 pandemic.

In compliance with all ethical precepts that govern research with human beings, the research was submitted to the Institutional Review Board of the Universidade do Estado do Rio de Janeiro in Brazil, in accordance with Resolution 466/2012, of the Brazilian National Health Council (Conselho Nacional de Saúde) ${ }^{(6)}$. Moreover, it was submitted to the Institutional Review Board of the Universidad de Alicante in Spain in accordance with Organic Law $3 / 2018$ of December $5^{(7)}$, and with the provisions of Regulation (EU) 2016/679 of the European Parliament and of the European Council of 27 April $2016^{(8)}$.

\section{Study design}

This is a qualitative, descriptive research, whose narrative outline is based on the ethnographic method. The aim is to identify subjective aspects related to the point of view, worldview and relationships that individuals establish, revealing the local culture of a group ${ }^{(9)}$. Nevertheless, considering the main researcher's doctoral study, the narrative seeks to understand the experience, identity and systems and values that nurses, as health workers in Primary Care, manifest to face crisis situations in the concrete work context ${ }^{(10-11)}$. Thus, on the one hand, it is a challenge to relativize the researcher's ethnocentrism, favoring an empathic understanding of the group; but, on the other hand, it is important to give a critical theoretical sense to the facts observed and experienced by the studied collective ${ }^{(12)}$.

The ethnographic text can be obliterated by the impersonality distanced from the object, moving away from the dialogic and situational aspects of the context, personally experienced by the researcher ${ }^{(13)}$. Considering these assumptions and the crossing of the pandemic for nurses and for the researcher, the narrative is 
also based on an interpretation related to "translation of our own culture to others"(14), in a way to allow us to understand ourselves in the process of interacting with the setting.

\section{Study design}

To guide this article, we used the Equator instrument called Standards for Reporting Qualitative Research (SRQR)(15), which defines a standard for qualitative research reports.

\section{Methodological procedures}

As data collection instruments, a field diary, participant observation and interview script were used, which are central to understanding the experience of coping with the crisis, relating it to the pandemic, based on the following questions: ¿Cómo ha afrontado usted los cambios generados por la crisis como enfermera comunitaria? ¿Qué recurso/s considera que ha/n podido contribuir a afrontar la crisis en APS? ¿Cómo ha contribuído? Furthermore, we sought to recover the records of field diaries and memory of personal experiences in the research, using the ethnographic narrative as a strategy to understand being a nurse in Primary Care, in the face of a serious health crisis and the experience of field research.

\section{Study setting}

The setting was in the Valencian Community, located in Spain in March 2020, in a Primary Care unit in the locality. The criterion for choosing the setting was related to the social and demographic characteristics of the territory, under the responsibility of the Primary Care teams and through the proximity to the setting by the authors' previous contact, being the same chosen for data collection in the doctoral stage in Spain.

\section{Data source}

The study initially had the participation of ten nurses and two nursing assistants who accepted to participate in the interviews and had been working for more than a year, constituting the focus of the doctoral thesis in the health unit in question. At first, follow-up was scheduled for three days with each professional, throughout the full workday, using notes from the ethnographic observations of work and the daily interaction between professionals contained in the field diary. However, it was possible to monitor four nurses in the field, whose names were changed, considering the interruption necessary in the face of the State of Alarm decree through Royal Decree 463/2020 of March 14, $2020^{(16)}$, for managing the health crisis caused by the coronavirus in the territory and the suspension of teaching and research in health units.

\section{Data collection and organization}

In addition to the informal conversations developed during the follow-up period, four in-depth interviews and participant observation were carried out, lasting about sixty-three hours in total and written in thirty-six pages of notes and records in a field diary. Formal interviews were recorded, with an average time of one hour for each interview. Then, they were transcribed and participants were identified with fictitious names: Carlos, Pablo, Paola and Claudia, chosen at random to preserve their identities. Field diary notes served to complement the speeches. Additionally, official reports from the Spanish Ministry of Health and journalistic news published in the media of the main public information vehicle in Spain (Spanish Television Network - STVN) were opportunely used to contextualize the period and the speeches.

\section{Data analysis}

The results are presented in narrative format, through domain analysis for data reflection. The objective of this type of analysis is to identify cultural domains, which are categories of cultural meaning $s^{(17)}$, related to the taxonomy of coping with the crisis in the work process, which was thus already related to the primary object of research of the project of doctorate degree. Also, reflective autoethnographic content was used to assess and raise awareness of intersubjective issues in the development of research ${ }^{(18)}$.

This text aims to carry out a first analysis regarding the period of ethnographic data collection in Spain, seeking to shed light on the contradictions, concerns and reflection as a researcher in the context of a cultural experience different from work in health. Immersion in the context of work allowed identifying two axes of domain, which will be presented in the format of storytelling about scenes, as a strategy to illustrate the ethnographic process: "The crisis, work in the community and the territory in Primary Care"; "The inevitability of being a nurse in facing a health crisis".

\section{RESULTS}

\section{Contextualization of the onset of the coronavirus pan- demic in Spain}

The news about the pandemic situation in Spain developed, as well as in the rest of the world, in a gradual process with many uncertainties through information about the path that transmission was taking, throughout the first months of 2020. Despite the news of the increased proximity of the contagion to the place where it was, field research activity was not presented as a restriction for data collection at that time. Although entry into the field was in no way hindered by its actors at the beginning of March, events were drawing a scenario of growing tension on the eve of the declaration of the State of Alarm ${ }^{(16)}$. On the second day of March, the coronavirus pandemic scenario in Spain was a warning, but without alarm: there were 119 confirmed cases in the country, 15 in the Valencian Community, where the research was carried out, according to official reports from the Ministry of Spanish Health ${ }^{(19)}$. The majority were imported cases, especially from Italy, the first cases of local contagion had been reported the week before in Sevilla and Madrid ${ }^{(20)}$.

The news requested tranquility, but with caution, to avoid widespread panic in the fight against the pandemic ${ }^{(21)}$, considering the fear related to news from the Italian context ${ }^{(22)}$, the risk of overloading the system health care ${ }^{(23)}$ and the respective initial reactions of exhaustion of masks, alcohol gel and gloves in pharmacies $^{(24)}$ and the fear of lack of supplies in the markets ${ }^{(25)}$. 
Locally, there was concern about the cancellation of the traditional Valencian festival of Fallas. Would it be cancelled? And if canceled, according to common sense ${ }^{(12)}$ in the locality and in informal conversations between professionals in the unit, it would represent the severity of the pandemic situation in Spanish territory. It did not take long for the news to come out on the Spanish Public Television Network of the decision to suspend the event: "Las Fallas de Valencia se aplazan por el coronavírus"(26). At this point, widespread fear would already be inevitable, given the alarm and the massive approach to the pandemic in the world's media.

In Spain, at least 15\% of the total number of infected people in the country were healthcare professionals, consistent with the situation of lack of personal protective equipment at the onset of the epidemic ${ }^{(2)}$. In this initial period, measures adopted by the Spanish health authorities focused on epidemiological surveillance and medical-hospital care, to the detriment of the role of Primary $\operatorname{Care}^{(3)}$. The silent arrival of the pandemic in Spain met the context of precariousness in the scope of Primary Care, already weakened by the insufficient number of healthcare professionals, diagnostic resources and personal protection equipment ${ }^{(3)}$. This fact did not take long to demonstrate its profound impact on the situation of the workforce, in terms of number of infected and deceased professionals who worked on the front lines in Primary Care ${ }^{(3,27)}$. It is about scenes from the days that preceded the first declaration of the State of Alarm ${ }^{(16)}$ which seeks to narrate nurses' experiences regarding the beginning of this process.

\section{"Decipher me or I will devour you": the crisis, work in the community and the territory in Primary Care}

Between comings and goings along the way of home visits, consultation breaks and conversations in the collective spaces of a healthcare center, approximations to the cultural context of nurses' work in Primary Care in Spain were established. The strangeness of the literally foreign researcher's presence in professionals' daily work was made relative as dialogue was informally established through sharing general information about the culture of the respective countries of origin. Distant realities, both in terms of material conditions and in terms of the cultural context of work, which; however, forged a relative integration into daily life of the professional group through workers' complacency towards the researcher. Experiences related to the effects of political economic crisis were reported in the immediate context of carrying out the work process in the Primary Care service.

Occupying the position of team nurse in Primary Care for over 10 years, Pablo pointed out his adaptation strategies, considering the difficulties associated with the economic-political crisis since 2009. From the drop in the quality of supplies used in care until the decrease in the hiring of professionals for replacement in the service's vacant posts, Pablo reported with dissatisfaction the increase in the workload after the application of Spanish fiscal austerity regime. In the dialogues established between the researcher and nurses, individual strategies for adapting professional practice were pointed out, seeking to mitigate the risks to users' health, and resilience and solidarity among health workers were identified as the main resources for dealing with political economic crisis: [we face the crisis] Trabajando más de lo que ha podido. $Y$ sobretodo intentando que, que no le afectara el menos posible a los pacientes. (Pablo)

Hay dependido del personal. Ha dependido de los que estábamos. Lo mismo que estábamos antes, ese es los que estamos ahora [...] No, no ha aumentado los recursos, ninguno. Ninguno, al revés: menos. Menos sustituciones [...] te vas de vacaciones y no te sustituyen, o sea, que ha habido menos. (Paola)

However, the new scenario of the COVID-19 health crisis was approaching the work context at the time the research was carried out at the healthcare center. Between the first and third day in the field, the topic of the pandemic was still restricted to informal dialogues among workers. In interactions and communications between healthcare professionals, especially in spaces of collective interaction (refectory, private balconies for professionals), the exchange of information about what had been discovered in relation to the "new" coronavirus' behavior and the exchange of views on coping and the situation of the pandemic in other countries.

It was the fourth day of fieldwork, March 6, 2020, when the pandemic situation began to manifest itself in the healthcare center. During home visits with Pablo, it was observed that users and family members expressed doubts and concerns about the situation of the pandemic. The answer to the questions was developed under the alert call to users. Nevertheless, it was possible to see that the concrete data on the pandemic at the local level were not clear to the primary care professionals at that time. Even so, they maintained a posture of security and tranquility in the transfer of the guidelines, even if they did not have much information about the situation of epidemiological surveillance in the territory.

The next day, it was possible to notice a conversation about the pandemic in the nursing coordination room at the healthcare center. Carlos and Pablo expressed concern about controlling the coronavirus in the country, and there was little information about the concrete situation of incidence of cases in the territory and in the community. Doubts and anxieties were shared regarding the protection of professionals in the unit and questions about access and use of personal protective equipment were also presented at all times. Information related to mobility restrictions in Italy and the rapid expansion of the pandemic in Spain, tripling the cases reported in Madrid in just a few days, and government measures to contain the transmission, could be followed by the main national news reports ${ }^{(28)}$.

Four days before the declaration of the State of Alarm ${ }^{(16)}$, a follow-up of Claudia's activities had been scheduled in the area covered by the unit. In the meantime, it was possible to observe contradictions in the approach to the territory. In Spain, territorialization is manifested in the administrative delimitation of the Basic Health Zone (BHZ), as a space for the location of Primary Care services, however, with little expression of the community character in guiding the work process of healthcare professionals. In this sense, in one of the interviews on the theme of the economic-political crisis, there were references to the commitment of community work in the face of the reduction of professionals and accumulation of attributions and procedures internally in 
health units, which had been developing since the framework of the political economic crisis:

[...] solo tengo dos manos, si queda el mismo número de profesionales tendré que dejar de hacer algunos encargos para hacernuevos. Y es un riesgo, porque en la Primaria lo que dejaría de hacer es la promoción y prevención de la salud. (Carlos)

Throughout the research process, there were ambivalent manifestations of professionals in relation to territorialization: on the one hand, reports on the increase in the demand for care and work overload, since in a given period, the enrollment was based on a territorial basis only for the nurse, while for the physician of the Primary Care team it was based on individual record (cupo):

Lo tenía yo pacientes de varios médicos, según la organización [by ascribed territories] [...] yo estaba organizando, los enfermeros estamos organizados a la mejor por zonas geográficas del barrio y ellos estaban organizados por cupos. Entonces ellos tenían gente en muchas zonas, pero yo solo me dedicaba a una zona, a lo mejor me correspondía esta zona que tenía gente de 6 médicos. (Pablo)

On the other hand, they highlighted the role of territorialization as an important resource for community work and for analyzing the cultural context in which people live:

[...] el ámbito comunitario es el ámbito de la Atención Primaria de Salud atender al individuo y adónde vive trabaja estudia, ¿vale? Pero tiene mucha más implicación de intervenir precisamente en ese nivel, en el nivel comunitario, fuera del centro, fuera del propio domicilio del paciente [...] es decir actuar en ámbitos que son propios de la comunidad, que no son propios del centro sanitario o del entorno individual del paciente. (Carlos)

Before the pandemic manifested itself in the scenario, this concern was perceived in relation to the contradictions related to community work. Before the outbreak of the pandemic at the site, workers shared reflections on the contradictions related to the role of the territory in Primary Care and in the (class) relationships between professional categories within the organization of work between nurses and physicians. On the other hand, the relationship between work processes and the idea of health surveillance based on understanding the dynamics of life of users in the community was not palpable in the daily service, bringing the following unanswered question: knowing the territory better Could it contribute to better prevention and thus make them feel more prepared to face the coronavirus situation in the area?

\section{"Es lo que hay": the inevitability of being a nurse in facing a health crisis}

The eighth day of research was scheduled to learn about the impacts of the economic-political crisis on the work process of one of the nurses, Claudia. In previous days, several reports on impacts related to the availability of inputs, human resources and demand for assistance had been collected. It was about observing Claudia's work in the daily schedule of appointments. However, the day began with the news given to healthcare professionals of suspension of their vacation and reorganization of activities at the healthcare center, as a result of the coronavirus pandemic: cancellation of group activities and consultations carried out only for priority ones, the rest being carried out by telephone when possible. Between one nursing consultation and another, conversations were established with Claudia, a nurse-midwife, who made clear the tension about the pandemic situation. For the researcher, at first, the dimension of the problem that she was following in the unfolding of the health crisis situation on-site with nurses in the health service was not perceived. Despite this, it was possible to observe systematic reports of users' concern, which ranged from the shortage of supermarkets in some locations to the insecurity related to the time of delivery. However, continuity of care has developed steadily, with a strong appeal to the relational aspect of work for welcoming and actively listening to users' anxieties. It can be said that professionals' high emotional demand became evident through sharing her own anxieties with the researcher between appointments. This requirement related to concerns about the protection of their family, healthcare professionals in general and the ethical choices that might have to be made in the event of an overload of the hospital system for care, resulting in a process of moral distress ${ }^{(29)}$ :

[...] tengo que tomar una decisión yo, sobre lo que hacer, si la [patient] expongo al riesgo en tener que irse en la próxima semana $u$ adelanto [hospital assessment of a condition that would require hospitalization to perform the procedure]: $i y$ ahora que hacer? Eso es un riesgo también. (Claudia)

The imponderables of the pandemic phenomenon became more palpable, as possible cases of symptomatic users inside the unit were perceived. Insecurity and uncertainty about what to do and how to deal with the events, which related to the little-known character of the coronavirus disease in the period, became, unequivocally, the tone of the actions. Experiencing the exact moment of the initial process of the serious health crisis, the researcher can contextualize nurses' narrative in relation to the aspects that contributed to coping with the economic-political crisis in action and the costs for workers:

[...] lo que ha salido para adelante durante la crisis, es el coraje de los trabajadores. Aquí la crisis se ha superado, en el sistema sanitario español, ha superado la crisis a base de los riñones de los trabajadores, así de claro. (Claudia)

Los recursos [to cope with the crisis] ha sido sobretodo los humanos. Los humanos y, aparte de los humanos, de los trabajadores de la sanidade [...]. (Pablo)

In the process of advancing the health crisis, debates about the impact of the pandemic in the country took place as the news was received, at an accelerated speed through the workers' personal social media. Opinions about the possible events that caused agglomerations and the delay in recognizing the seriousness of the virus' spread throughout the country were brought to the scene in the dialogues. Moreover, it was possible to observe reflections in the interaction and conversations between professionals in different spaces of the unit, especially about working conditions and protection for health workers. 
Considering the news about contamination and deaths among healthcare professionals, the theme of safety at work was at the center of debates among nurses, directly dialoguing with previous reflections on the effects of the political economic crisis on working conditions and care for users in the health system. In the reports on the experience of coping with the crisis caused by the budget constraint, the commitment to the maintenance of care, mainly from the understanding of the expansion of population's health needs at this juncture, was presented as a support value strongly subjectified in nurses' work, even under adverse conditions:

[...] jintentando ayudar siempre! Todo lo que puedes y hasta dónde puedes, a cada persona. Cuándo llegas a un punto en que no puedes hacer más [...] pues, si realmente te das cuenta de que no puedes hacer más, pues la asumes, pero no te rindes. Es decir, intentas ser profesional todos los días, intentas ver realmente la persona que tiene delante, cada vez que tienes una persona delante, y intenta comprender qué cosas son las que necesita. $Y$ intentas aquellas que sí, que puedes darle, bueno, que le puedes ayudar, pues hacer dentro de las posibilidades y de los medios que tienes. (Carlos)

On the other hand, the tension in the unit in relation to the pandemic was widespread, implying a considerable change in professionals' behaviors and attitudes, who were visibly concerned and in exclusive attention to the necessary work adaptations. Direct approaches, with direct questioning about the researcher's safety, had also taken place on the eve of the suspension of teaching and research activities by the Spanish state. Self-reflection on data collection in the field was also encouraged by the intercultural dialogue with professionals: the (inevitable?) risk of the profession was established within a setting that would be research. To what extent did taking on the possibility of opposing oneself in the field, as a researcher, naturalize the risk of the occupational risk of being a nurse?

Changes in the behavior of the professional group were perceived as signs of discomfort with the investigation process, in a setting of uncertainty and preparation to face the serious unknown that was taking place. The context turned out to be an ethical dilemma for the investigation. The difficulty in continuing the stages of interviews seemed to be, in fact, drawing the impossibility of continuing the research. Faced with this situation, the recognized leadership among nurses was sought to share the anguish and assessment of continuity of research in the health crisis scenario, respecting the trusting relationships between the researcher and the research subjects. In a conversation directed at Carlos about the ethical question of the research, obstacles were raised to pay attention to the researcher in this context, despite the verbal expression of recognition of the importance of research in the context of qualitative change in coping with the crisis. The ambivalence identified and the changes presented in the behavior of the professional group guided the decision to discontinue data collection.

Aún ayer hablábamos sobre los efectos de 2008 sobre nuestro trabajo, hoy estamos viviendo un nuevo escenario que se cambió, es una crisis sanitaria y estás en el ojo del huracán. (Carlos)

\section{DISCUSSION}

Professional identity, understood as a set of moral, ethical and social values and principles, part of the feeling of belonging to the group and to a professional culture that, in nursing, is related to planning and care values, synthesized in a social practice of protection of life ${ }^{(30-31)}$. The difference between the Spanish and Brazilian realities is immediately felt when following the daily work and territory in Primary Care. Although the common axis of action is professional identity and the purpose of care is comprehensive health care and care for individuals, families and communities (geographically located in a determined territory and assigned to a team composed of physicians and nurses), the material context and the symbolic universe related to nursing work develops in different ways and adheres to daily life and to the objective and intersubjective relationships produced in the lived context.

The professional group cohesion was one of the most visible elements in the observation carried out within the work context of nurses in Primary Care in Spain. This manifestation presents itself in the establishment of practice adaptation strategies to support nursing care, based on the assumptions of professional identity ${ }^{(32)}$, mainly in the collective organization to face the difficulties in the services as health workers. In this sense, the group presents a system of values related to the defense of healthcare to users, especially through cooperation and solidarity among workers to sustain assistance and in the struggle for improvements in material working conditions in the face of crisis situations.

We live in a difficult period for humanity, the pandemic represents a tragedy for humanity in the $21^{\text {st }}$ century; however, we cannot say that this tragedy was no longer announced ${ }^{(33)}$. No, precisely because we are experiencing a historical process of exhaustion of the socio-metabolic system of global capital that has already demonstrated the activation of its structural limits since the end of the last century ${ }^{(5,34)}$. In this perspective, it is the very unstoppability and irrestrictability of the expansion of capitalist accumulation ${ }^{(5)}$, which demonstrates its destructive aspect in the living, working and health conditions of the working class and in the very conditions of existence on the planet, considering its devastating action of the natural environment with direct consequences in the emergence of zoonotic epidemics ${ }^{(33,35)}$. Epidemic processes are considered one of the most acute aspects of the development of the capitalist accumulation process, demonstrating the structural character of the crisis in capitalism and its respective social determination of the health-disease process ${ }^{(4,35)}$.

In this key of understanding, the pandemic manifests the conditions of denial of freedom and reductions in the subsistence level of the working class, making explicit the class character of the State ${ }^{(5,34,36)}$ that, to the detriment of social rights, services and healthcare professionals sufficient to meet users' health needs, it ends up manifesting "(...) la negación institucionalizada y sacramentada de los cuatro principios que hacen posible el buen viviry la salud: la sustentabilidad, la soberanía, la solidaridad y la seguridad integral en los espacios y sujetos de la vida."(33) Environmental destruction, chronic unemployment, restriction of freedom of broad masses, especially among women, blacks, indigenous people and immigrants ${ }^{(5,33-35)}$, generate disastrous consequences for the 
health of users who seek assistance from healthcare professionals in public services scrapped by fiscal austerity ${ }^{(37-38)}$. They also suffer from the limits of their performance in an attempt to provide individual responses to the serious social problems that affect the collective health of a growing contingent of the population ${ }^{(4,38-39)}$. They observe with some perplexity the impact of COVID-19 on the population already ill due to a process of precariousness of life that precedes the pandemic ${ }^{(4,35,39)}$. Faced with the unfunded health policy, the pandemic calls into question the ethical and humanitarian dimension of the crisis.

It should be remembered that the crisis process has been manifesting itself with vigor since $2008^{(37-38,40)}$. "The ongoing crisis is a capitalist crisis, albeit with health determinations"(36). The way in which health services, especially public ones, were made vulnerable to fight the pandemic is related to the dismantling of public services and the expropriation of social rights - lack of personal protective equipment, shortage of beds, lack of healthcare professionals - with greater impacts in peripheral countries ${ }^{(41-42)}$. Although the historic Welfare State, rooted in the collective consciousness and political agenda of the Spanish working class, has favored the resistance of public health services, the system has suffered severe blows of disintegration over the last 10 years ${ }^{(43)}$.

The feeling of uncertainty in relation to the events crosses the scene in Spain in a forceful way. For Primary Care nurses, the experience of facing the political economic crisis is revealed in an act during the field research: it is through "riñones de los trabajadores" that, even under visible tension, they organized collectively to support themselves in the production of care and self-protection, in the serious scenario of outbreak of the pandemic in the area. It can be said that, in terms of work culture ${ }^{(10-11)}$, the value of cooperation and solidarity among workers is palpable in that context. The rapid and strong collective organization of the group is noticeable in the concrete context, considering that, in terms of class relations, the conditions of stability and the lower incidence of hierarchization and social division of labor within the category favor horizontal dialogue and relationships of class solidarity among nursing professionals.

On the other hand, the contradictions associated with the role of the territory in community work are perceived in coping with COVID-19 with the population served by the teams. This fact arouses reflection on professional practice in Brazilian Primary Care. Considering the specific context of social inequality and the political situation in Brazil, the difficulty in dealing with the problem takes on greater and proportionally more serious contours in view of such precariousness in users' lives. Furthermore, for daily professional practice of nursing in Primary Care, the question arises: to what extent is there time and material conditions necessary to systematically monitor the context and dynamics of users' community life?

In the case of the Brazilian reality, a Community Health Worker (CHW) can decisively contribute to the work of monitoring and popular education in the territory. But, given the accelerated dismantling of the Unified Health System (SUS - Sistema Único de Saúde) in the last 5 years, with a high loss of professionals in teams ${ }^{(42,44)}$, community guidance in Primary Care would be in the background as observed in the Spanish context ${ }^{(45-46)}$. Nevertheless, the pandemic reveals the importance of the territory and community guidance in the organization of the work process in Primary Care, especially for professional performance in the health crisis. If the context of life and the dynamics of users' relationship with their territory is not recognized by the teams, isolated clinical practice is incapable of effectively coping with the pandemic and promoting health. Therefore, it limits the power of action of healthcare professionals to contain the community transmission of COVID-19. This fact explains the difficulty in monitoring the transmission dynamics and effectively controlling the pandemic in the territories of communities, neighborhoods and villages.

Another issue pointed out and worthy of discussion was the crisis narrated during the increase in cases and the time to continue data collection and to stop the research, during the first moments of the pandemic. To what extent is the initial assessment of the researcher, nurse, related to the system of values in nursing ("continue helping") and to the context of precarious work in the country of origin? However, it is still necessary to ratify the relevance of the researcher's permanent exercise of self-reflection during data collection in participant observation. The use of sensitivity was fundamental in the perception of participants' emotional aspects involved in the concrete context of field research. In this way, it is reinforced that the involvement of the research subjects must be active, respecting trusting relationships and always prioritizing participants' autonomy, freedom, and dignity. The intercultural dialogue involved in ethnographic research allowed for self-reflection on professional practice and field research in this context of health crisis.

"Es lo que hay" was an expression heard by one of nurses when referring to the concrete context of their work process after the 2008 crisis. The use of this expression in the text is made in reference to the precariousness of work and the support and defense of life, supporting health care in the difficult moment of the COVID-19 pandemic within the limits of its own professional health. It is we healthcare professionals, and nursing professionals in particular, who are in the "eye of the hurricane" within the health system, in frank disruption by successive political economic crises, seeking to give our best to fight the pandemic, but living hard with their overlapping and deepening impacts in the most serious health crisis of the last century caused by COVID-19(33,42-43,47). Despite the strength of values that support nurses' work in Primary Care in different countries, it is necessary to fight for decent conditions for nursing work through public systems that guarantee the universal right to health for the population. In this way, the repeal of austerity measures and a new project for life, health and society should be the main focuses of struggle for society as a whole, considering that they affect not only the responsiveness of services to the increase in care demands, but they take away human dignity and the value of life from the population.

\section{Study limitations}

The possible limitation is due to the fact that it was carried out in a single setting, the observation time and linguistic differences. Given the situation of the rapid onset of the pandemic and the suspension of training and research activities during the period by the Spanish government, it was not possible to proceed with data collection within the units and expand the research to other 
scenarios in Spain. Nevertheless, it is understood that these are notes that reflect the reality of the impact of crises on nursing work at the time of the pandemic.

\section{Contributions to nursing and public health}

It is understood that this study can contribute to the reflection of research ethics in nursing and health, mainly to point out the impacts of disruption of public health services and its consequences in facing the serious global health crisis for nursing and attention to the population's health. It is believed to contribute to strengthening community guidance in the work of nursing in Primary Care, as well as strengthening the valuation of the category through better working conditions and structured public health services capable of coping with the population's health needs.

\section{FINAL CONSIDERATIONS}

The process of expanding opportunities for research at the international level brings challenges for the researcher in the field of nursing that are independent of the local health situation found, but they end up being expanded and can become real problems when the context changes as quickly as in the case of the introduction from COVID-19 in Spain brought into this ethnographic narrative. The experience of research in foreign territory at the beginning of the COVID-19 pandemic resulted in ethical dilemmas during data collection on the work process in primary healthcare. Crises expose us as professionals to insecurity at work due to the seriousness of work and population life precariousness. However, it is important to highlight professional identity, values and coping experience employed by nursing workers. Furthermore, it can be seen that the collective organization capacity of workers and the bonds of solidarity and cooperation in the class relationship is fundamental in facing the deepening of the capitalist structural crisis. In this regard, the lesson to be learned is global - either we move towards strengthening professionals working conditions, Primary Care and community guidance, or we will be increasingly at the mercy of destructive waves governed by the exclusionary relations of capitalism prevailing in the world.

\section{FUNDING}

This study was carried out with the support and funding of the Coordination for the Improvement of Higher Education Personnel (CAPES - Coordenação de Aperfeiçoamento de Pessoal de Nível Superior).

\section{REFERENCES}

1. World Health Organization. WHO director-generals statement on the advice of the ihr emergency committee on novel coronavirus [Internet]. Geneva:WHO; 2020[cited 2020 Dec 7]. Available from: https://www.who.int/dg/speeches/detail/ who-director-general-s-statement-on-the-advice-of-the-ihr-emergency-committee-on-novel-coronavirus

2. Minué Lorenzo S. La pandemia COVID-19: lo que hemos aprendido hasta ahora desde España. APS Rev. 2020;2(1):28-32 https://doi. org/10.14295/aps.v2i1.66

3. Sociedad Española de Salud Pública y Administración Sanitaria. Posicionamiento SESPAS sobre el rol de la atención primaria de salud ante la epidemia de COVID-19 [Internet]. Barcelona: Sespas; 2020[cited 2020 Dec 7];1-5 Available from: https://sespas.es/2020/04/21/ posicionamiento-sespas-sobre-el-rol-de-la-atencion-primaria-de-salud-ante-la-epidemia-de-covid-19/

4. Stark E. The epidemic as a social event. Int J Health Serv. 1977;7(4):681-705. https://doi.org/10.2190/RKRQ-WV6E-DV53-VATT

5. Mészáros I. Para além do capital: rumo a uma teoria da transição. São Paulo: Boitempo Editorial; 2011.

6. Ministério da Saúde (BR). Resolução no 466, de 12 de dezembro de 2012. Aprova as diretrizes e normas regulamentadoras de pesquisas envolvendo seres humanos e revoga as Resoluções CNS nos. 196/96, 303/2000 e 404/2008. Brasília, DF: MS; 2012.

7. Jefatura del Estado (ES). Ley orgánica 3/2018, de 5 de diciembre, de Protección de Datos Personales y garantía de los derechos digitales. Bol Of Estado [Internet]. 2018[cited 2020 Dec 7];(294):119788-857). Available from: https://www.boe.es/eli/es/lo/2018/12/05/3

8. European Parliament and of The Council. Regulamento (UE) 2016/679 do Parlamento Europeu e do Conselho, de 27 de abril de 2016 , relativo à proteção das pessoas singulares no que diz respeito ao tratamento de dados pessoais e à livre circulação desses dados e que revoga a Diretiva 95/46/CE. Of J Eur Union [Internet]. 2016[cited 2020 Dec 7]:L119/1. Available from: http://data.europa.eu/eli/ reg/2016/679/oj

9. Malinowski B. Os argonautas do pacífico ocidental: um relato do empreendimento e da aventura dos nativos nos arquipélagos da Nova Guiné Melanésia. In: Etnologia. 3a ed. São Paulo: Abril Cultural; 1997. p. 17-37.

10. Mattos MB. Cultura e "algo que não é cultura": um debate a partir do marxismo inglês. In: Albuquerque GG, Velasques MCC, Batistella RR, organizadores. Cultura, politecnia e imagem [Internet]. Rio de Janeiro: EPSJV; 2017[cited 2020 May 20]. p. 49-64. Available from: https:// www.epsjv.fiocruz.br/sites/default/files/livro_cultura_politecnia.pdf

11. Velasques MCC. Cultura do trabalho como cultura de classe: anotações para o estudo e a fabricação da história dos trabalhadores da saúde. In: Albuquerque GG, Velasques MCC, Batistella RR, organizadores. Cultura, politecnia e imagem [Internet]. Rio de Janeiro: EPSJV; 2017[cited 2020 May 20]. p. 91-112. Available from: https://www.epsjv.fiocruz.br/sites/default/files/livro_cultura_politecnia.pdf

12. Crehan K. Antonio Gramsci: em busca de um marxismo etnográfico. Rev Outubro [Internet]. 2018[cited 2020 Dec 7];(30):129-42. Avaible from: http://outubrorevista.com.br/wp-content/uploads/2018/05/06_Kate-Crehan.pdf 
13. Versiani DB. Autoetnografia: uma alternativa conceitual. Let Hoje [Internet]. 2013[cited 2020 Dec 7];37(4):41-56. Avaible from: https:// revistaseletronicas.pucrs.br/ojs/index.php/fale/article/view/14258

14. Bossle F, Molina Neto V. No "olho do furacão": uma autoetnografia em uma escola da rede municipal de ensino de Porto Alegre. Rev Bras Cienc Esporte [Internet]. 2009[cited 2020 Dec 7];31(1):131-46. Avaible from: http://www.oldarchive.rbceonline.org.br/index.php/RBCE/article/view/639

15. O'Brien BC, Harris IB, Beckman TJ, Reed DA, Cook DA. Equator instrument Standards for Reporting Qualitative Research: a synthesis of recommendations. Acad Med. 2014;89(9):1245-51. https://doi.org/10.1097/ACM.0000000000000388

16. Ministerio de la Presidencia(ES). Relaciones con las Cortes y Memoria Democrática. Real Decreto 463/2020, de 14 de marzo, por el que se declara el estado de alarma para la gestión de la situación de crisis sanitaria ocasionada por el COVID-19 Bol Of Estado [Internet]. 2020[cited 2020 Dec 7];(67):25390-400. Available from: https://www.boe.es/eli/es/rd/2020/03/14/463

17. Spradley JP. The ethnographic interview. Forth Worth: Hancourt Brace Jovanovich College; 1979.

18. Santos SMA. O método da autoetnografia na pesquisa sociológica: atores, perspectivas e desafios. Plural. 2017;24(1):214-41. https://doi. org/10.11606/issn.2176-8099.pcso.2017.113972

19. Ministerio de Sanidad (ES). Informe sobre los casos de COVID-19 confirmados en España. Informe COVID-19 [Internet]. 2020 [cited 2020 Dec 7];(4):1-6. Available from: https://www.isciii.es/QueHacemos/Servicios/VigilanciaSaludPublicaRENAVE/EnfermedadesTransmisibles/ Documents/INFORMES/Informes COVID-19/Informe COVID-19. No 4_02marzo2020_ISCIII.pdf

20. Ministerio de Sanidad (ES). Informe sobre los casos de COVID-19 confirmados en España. Informe COVID-19 [Internet]. 2020 [cited 2020 Dec 7];(3):1-5. Available from: https://www.isciii.es/QueHacemos/Servicios/VigilanciaSaludPublicaRENAVE/EnfermedadesTransmisibles/ Documents/INFORMES/Informes\%20COVID-19/Informe\%20COVID-19.\%20N\%C2\%BA\%203_28febrero2020_ISCIII.pdf

21. RTVE. Especial informativo Coronavirus: combatir el miedo [Video]. 2020 Mar 4[cited 2020 Dec 7]. [presentation: 52 min 8 seg]. Available from: https://www.youtube.com/watch?v=ij83gGesF8E

22. Italia cerrará escuelas y universidades en todo el país desde mañana hasta el 15 de marzo por el coronavirus. RTVE.es [Internet]. 2020 Mar. 4 [cited 2020 Dec 7]. Available from: https://www.rtve.es/noticias/20200304/italia-planea-cerrar-escuelas-universidades-todo-pais-hastamediados-marzo-coronavirus/2005329.shtml

23. Pilar SA. Coronavirus: el riesgo de colapsar el sistema sanitario por culpa del miedo. RTVE.es. [Internet]. 2020 Feb. 28 [cited 2020 Dec 7]. Available from: https:/www.rtve.es/noticias/20200228/coronavirus-cuando-miedo-mas-contagioso-propia-enfermedad/2004745.shtml

24. Sánchez A. El coronavirus deja a las farmacias sin mascarillas, geles desinfectantes y guantes RTVE [Internet]. 2020 Mar. 05 [cited 2020 Dec 7]. Available from: https://www.rtve.es/noticias/20200305/coronavirus-desabastecimiento-farmacias-mascarillas-geles-guantes/2005742.shtml

25. Los supermercados descartan el riesgo de desabastecimiento tras registrar largas colas y alta demanda. RTVE.es. [Internet]. 2020 Mar. 10[cited 2020 Dec 7]. Available from: https://www.rtve.es/noticias/20200310/supermercados-descartan-riesgo-desabastecimiento-trasregistrar-largas-colas-alta-demanda/2007961.shtml

26. Martín J. Las Fallas de Valencia se aplazan por el coronavirus. RTVE.es. [Internet]. 2020 Mar. 10[cited 2020 Dec 7]. Available from: https:// www.rtve.es/noticias/20200310/fallas-valencia-se-aplazaran-coronavirus/2008240.shtml

27. Ministerio de Sanidad (ES). Informe sobre la situación de COVID-19 en personal sanitario en España a 14 de mayo de 2020 [Internet]. Madrid: ISCIII; 2020[cited 2020 Dec 7]. Available from: https:/www.isciii.es/QueHacemos/Servicios/VigilanciaSaludPublicaRENAVE/EnfermedadesTransmisibles/ Documents/INFORMES/Informes\%20COVID-19/COVID-19\%20en\%20España.\%20Situación\%20en\%20Sanitarios\%20a\%2030\%20de\%20abril\%20 de\%202020.pdf

28. Sánchez anuncia un plan de choque contra el coronavirus y pide unidad frente a las críticas de la oposición. RTVE.es. [Internet]. 2020 Mar. 9 [cited 2020 Dec 7]. Available from: https://www.rtve.es/noticias/20200309/sanchez-anuncia-plan-choque-frente-coronavirus-pide-unidadfrente-criticas-oposicion/2007581.shtml

29. Barth PO, Ramos FRS, Barlem ELD, Dalmolin GL, Schneider DG. Validation of a moral distress instrument in nurses of primary health care. Rev Latino-Am Enfermagem. 2018[cited 2020 Dec 7];26:e3010. https://doi.org/10.1590/1518-8345.2227.3010

30. Bellaguarda MLR, Padilha MI, Nelson S. Eliot Freidson's sociology of professions: an interpretation for health and nursing. Rev Bras Enferm. 2020;73(6):e20180950. https://doi.org/10.1590/0034-7167-2018-0950

31. Zoboli ELCP, Schveitzer MC. Nursing values as social practice: a qualitative meta-synthesis. Rev Latino-Am Enfermagem. $2013 ; 21$ (3):695-703. https://doi.org/10.1590/S0104-11692013000300007

32. Martinez-Riera JR. Identity of the nurse in the society of rationalism. Rev Bras Enferm. 2019;72(5):1127-8. https://doi. org/10.1590/0034-7167-2019720501

33. Breilh J. COVID-19: determinación social de la catástrofe, el eterno presente de las políticas y la oportunidad de repensarnos. Andino [Internet]. 2020[cited 2020 Dec 7];(2):8-14. Available from: https://repositorio.uasb.edu.ec/bitstream/10644/7396/1/03-EN-Breilh.pdf

34. Mascaro AL. Crise e pandemia. São Paulo: Boitempo; 2020.

35. Lima NT, Buss PM, Paes-Sousa R. COVID-19 pandemic: a health and humanitarian crisis. Cad Saude Publica. 2020;36(7):e00177020. https:// doi.org/10.1590/0102-311х00177020

36. Gouvêa MM. A culpa da crise não é do vírus. In: Moreira E, Gouveia R, Garcia J, Acosta L, Botelho M, Rodrigues M, et al., organizadores. Em tempos de pandemia: proposta para a defesa da vida e de direitos sociais [Internet]. Rio de Janeir: UFRJ; 2020 [cited 2020 Dec 7]. p. $12-27$. Available from: http://www.cress-es.org.br/wp-content/uploads/2020/05/1_5028797681548394620.pdf 
37. Cantero Martínez J. Crisis y mutación del servicio público sanitario en España. Derecho PUCP. 2016;(76):251-76. https://doi.org/10.18800/ derechopucp.201601.010

38. Sánchez-Recio R, Alonso JP, Aguilar-Palacio I. The use of health care services in the great recession: evaluating inequalities in the Spanish context. Gac Sanit. 2020;34(3):245-52. https://doi.org/10.1016/j.gaceta.2019.10.009

39. Granero-Lázaro A, Blanch-Ribas JM, Roldán-Merino JF, Torralbas-Ortega J, Escayola-Maranges AM. Crisis in the health sector: Impact on nurses' working conditions. Enferm Clin. 2017;(3):163-71. https://doi.org/10.1016/j.enfcli.2017.03.005

40. Martínez-Riera JR. Crisis y enfermeras. Rev Rol Enferm [Internet]. 2012[cited 2020 Dec 7];35(2):108-19. Available from: https://rua.ua.es/ dspace/bitstream/10045/35568/1/2012_Martinez-Riera_ROL.pdf

41. Mendes Á. A saúde pública brasileira no contexto da crise do Estado ou do capitalismo?. Saude Soc. 2015;24(suppl 1):66-81. https://doi. org/10.1590/s0104-12902015s01006

42. David HMSL, Acioli S, Silva MRF, Bonetti OP, Passos H. Pandemics, crisis conjunctures, and professional practices: what is the role of nursing with regard to Covid-19?. Rev Gaucha Enferm. 2020;42(spe):e20200254. https://doi.org/10.1590/1983-1447.2021.20190254

43. Borges FT, López Fernández LA, Campos GWS. Austerity measures on fiscal policy: an attempt to dismantle the spanish national health system and citizen resistance. Saude Soc. 2018;27(3):715-28. https://doi.org/10.1590/s0104-12902018180043

44. Martins ALX, David HMSL. Crisis and nursing in primary care: notes of social practice by dialectical historical materialism. Rev Enferm UERJ. 2019;27:e42472. https://doi.org/10.12957/reuerj.2019.42472

45. Martínez Cía N, Pérez Pérez M, Heras-Mosteiro J, Gutiérrez Ávila G, Díaz-Olalla JM, Ruiz-Giménez Aguilar JL. Encuentros y desencuentros entre salud comunitaria y sistema sanitario español: informe SESPAS 2018. Gac Sanit. 2018;32(suppl 1):17-21. https://doi.org/10.1016/j. gaceta.2018.06.004

46. Martínez Riera, JR, Gras-Nieto, E. Cuidados domiciliares e covid-19: antes, durante e após o status do alarme. Enferm Clinica. 2020;31(suppl 1):s24-8. https://doi.org/10.1016/j.enfcli.2020.05.003

47. David HMS, Martínez-Riera JR, Acioli S, Costa MFL. Perceptions of Spanish Nurses on economic crisis and the impacts on health care system. Rev Bras Enferm. 2020;73(3):e20190283. https://doi.org/10.1590/0034-7167-2019-0283 